\title{
Clinicopathological Significance of the ET Axis in Human Oral Squamous Cell Carcinoma
}

\author{
Hiroki Miyazawa ${ }^{1} \cdot$ Koroku Kato $^{1} \cdot$ Yutaka Kobayashi $^{1} \cdot$ Mariko Hirai $^{1} \cdot$ lyo Kimura ${ }^{2} \cdot$ Hiroko Kitahara $^{1}$. \\ Natsuyo Noguchi ${ }^{1}$ - Hiroyuki Nakamura ${ }^{1}$. Shuichi Kawashiri ${ }^{1}$
}

Received: 21 November 2017 / Accepted: 18 October 2018 / Published online: 31 October 2018

(C) The Author(s) 2018

\begin{abstract}
The interaction between cancer cells and the surrounding microenvironment in malignant tumor tissue is known to be closely associated with cancer cell invasion and proliferation. Endothelin (ET) present in the microenvironment surrounding tumors has been reported to play a role in cancer cell invasion and proliferation by binding to receptors on the cell membrane of cancer cells. Here, we immunohistologically detected the expression of ET-1 and its receptor $\mathrm{ET}_{\mathrm{A}} \mathrm{R}$ in oral squamous cell carcinoma (OSCC) and evaluated the association between the expression of each as well as their co-expression (ET-axis expression) and clinicopathological factors. A significant difference was observed between the invasion pattern as a parameter of cancer cell malignancy and the expressions of ET-1 and $\mathrm{ET}_{\mathrm{A}} \mathrm{R}$. The survival rates were significantly lower among the patients who were strongly positive for ET-1 and the $\mathrm{ET}_{\mathrm{A}} \mathrm{R}$-positive patients compared to negative patients. There was also a significant difference between ET-axis expression and the degree of histological differentiation and mode of invasion, and the survival rate of the positive cases was significantly lower than that of the negative cases. Our findings suggested that ET-axis assessments are important for assessing the malignancy of cancer cells and predicting the prognoses of OSCC patients.
\end{abstract}

Keywords Endothelin $\cdot \mathrm{ET}-1 \cdot \mathrm{ET}_{\mathrm{A}} \mathrm{R} \cdot \mathrm{ET}$-axis $\cdot$ Oral squamous cell carcinoma $\cdot$ Prognosis

\section{Introduction}

For many years in Japan, malignant tumors have been the most common cause of death, and due to aging of the population the number of cancer patients in the country has been increasing [1]. Oral cancer accounts for approx. $3 \%$ of all cancers. Although this percentage is low, there are many patients with oral cancer for whom treatment is difficult, and poor outcomes despite treatment are often observed. In such a situation, drugs targeting molecules involved in cancer cell proliferation have been developed. Some of these drugs are now used clinically,

Koroku Kato

k-koroku@oral.m.kanazawa-u.ac.jp

1 Department of Oral and Maxillofacial Surgery, Kanazawa University Graduate School of Medical Science, 13-1 Takara-machi, Kanazawa 920-8641, Japan

2 Department of Oral and Maxillofacial Surgery, Nanto Municipal Hospital, 938 Inami, Nanto 932-0211, Japan but the numbers of responders to these drugs are limited, and novel treatment methods and drugs are necessary.

Many studies of factors associated with cancer cell proliferation, invasion, and metastasis have shown the close involvement of the microenvironment around the tumor, such as stroma cells and vascular endothelial cells [2-5]. The peptide hormone endothelin (ET) forms the ET axis by binding to its receptors, and it is involved in vasoconstriction and cell proliferation [6-10]. ET is composed of 21 amino acid residues. There are three types of ET (ET-1, -2 , and - 3) and two types of receptor $\left(\mathrm{ET}_{\mathrm{A}} \mathrm{R}\right.$ and $\left.\mathrm{ET}_{\mathrm{B}} \mathrm{R}\right)$. Concerning the association between ET and cancer, ET is known to be involved in cancer cell proliferation, invasion, and metastasis, and the ET family has been reported to induce epithelial-mesenchymal transition (EMT) [11-16]. ET-1 binds to $\mathrm{ET}_{\mathrm{A}} \mathrm{R}$ with high affinity, and high expressions of ET- 1 and $\mathrm{ET}_{\mathrm{A}} \mathrm{R}$ in tumor tissue have been reported in patients with highly malignant prostatic cancer accompanied by bone metastasis [11, 12].

Among patients with oral squamous cell carcinoma (OSCC), high ET-1 expression has been reported in OSCC patients with a poorly differentiated tumor accompanied by lymph node metastasis. However, there have been no studies 
on the importance of the expression of the ET axis (i.e., the coexpression of ET-1 and its receptor), and this axis is still poorly understood. Therefore, to evaluate the importance of ET-1 and $\mathrm{ET}_{\mathrm{A}} \mathrm{R}$ expressions and their co-expression, we evaluated the expressions of ET- 1 and $\mathrm{ET}_{\mathrm{A}} \mathrm{R}$ constituting the ET axis, and analyzed their association with clinicopathological factors and prognosis in patients with OSCC.

\section{Materials and Methods}

\section{Tissue Samples}

The subjects were 74 patients who visited the Department of Oral and Maxillofacial Surgery of our hospital between January 2000 and December 2015, underwent surgical resection or tissue biopsy, and were histopathologically diagnosed with OSCC. There were 36 males and 38 females aged 2989 years (mean, 63.8 years). The Union for International Cancer Control (UICC) system (ver. 7) [17] was used for the TNM classification and the clinical stage; the classification by the World Health Organization (WHO) are used for the degree of differentiation, and Yamamoto's classification [18] was used for the cancer invasion pattern.

\section{Immunohistochemistry}

To confirm ET-1 and $\mathrm{ET}_{\mathrm{A}} \mathrm{R}$ expressions in tissue samples from OSCC patients, we performed immunohistochemical staining. Each tissue sample was fixed in $10 \%$ buffered formalin (Sigma-Aldrich Japan, Tokyo), embedded in paraffin, and cut into serial sections (approx. $4 \mu \mathrm{m}$ ). After deparaffinization and antigen activation, immunostaining was performed using the catalyzed signal amplification (CSA) method. As the primary antibodies, Anti-Endothelin 1 antibody (Abcam, Cambridge, MA) and Anti-Endothelin A Receptor antibody (Abcam) diluted 500-fold in phosphate-buffered saline (PBS) were used. To evaluate the specificity of the staining, we used Universal Negative Control for IS-Series Rabbit Primary Antibodies (Dako Japan, Tokyo) as a negative control. For chromogenic detection, 3, 3'-diaminobenzidene tetrahydrochloride (DAB) was used. As a counterstain, Mayer's hematoxylin was used.

\section{Evaluation of Staining}

Staining was evaluated based on the number of stained tumor cells using a modification of Kato's method [19]. ET-1 and $\mathrm{ET}_{\mathrm{A}} \mathrm{R}$ expressions were evaluated by an immunoassay and were examined for three fields of invasive front per specimens by microscopy at $100 \times$ magnification. The percentage of positive cells was calculated as the proportion of positive cells among 500 cancer cells in each field. For both ET-1 and $\mathrm{ET}_{\mathrm{A}} \mathrm{R}$, the threshold for positive cases was set at $50 \%$ close to the median; cases with a positive cell proportion $<50 \%$ were categorized as weakly positive cases, and the $\geq 50 \%$ cases were considered strongly positive cases. A case that was not stained at all was counted as negative.

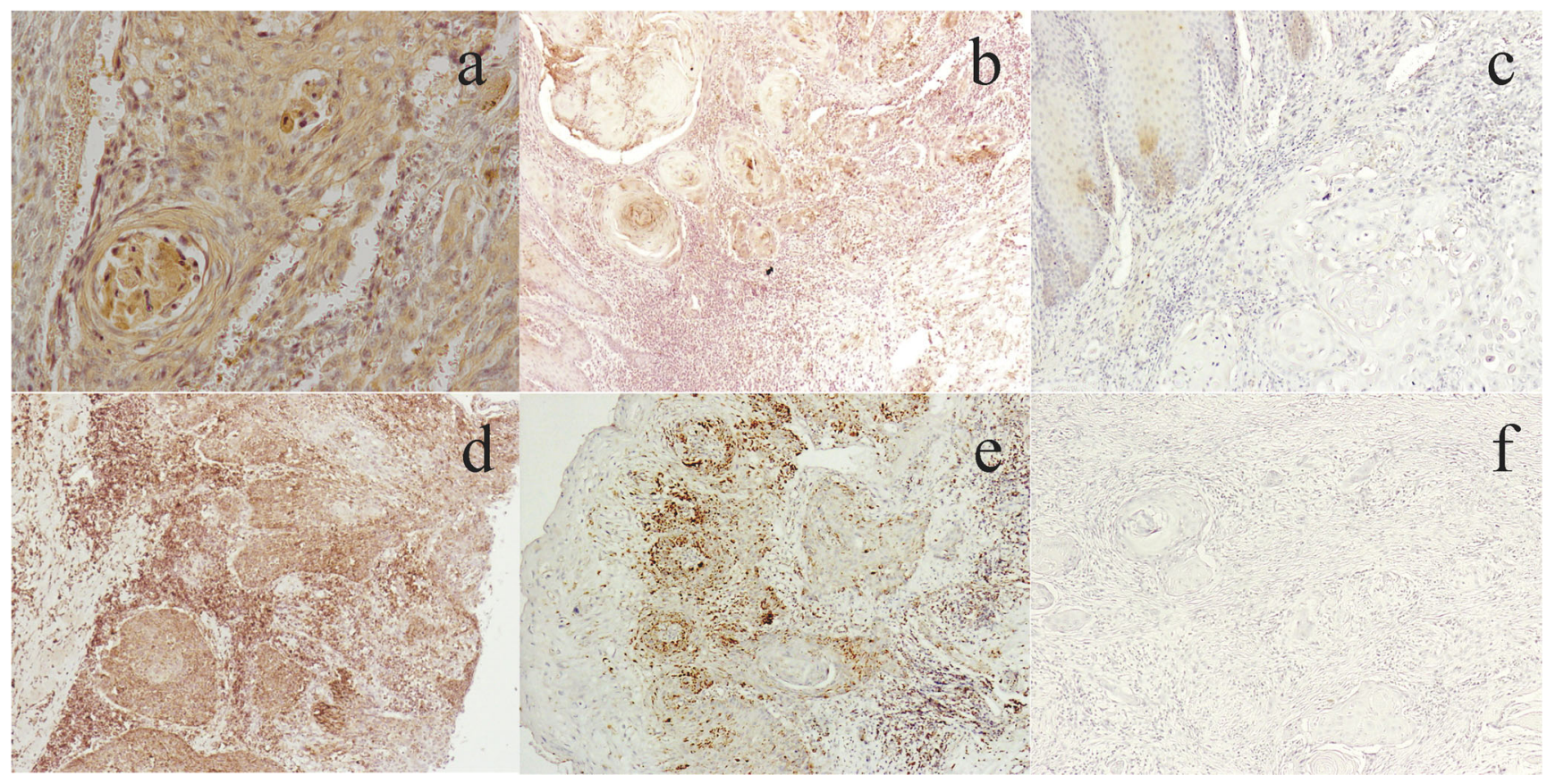

Fig. 1 Immunohistochemical staining of ET-1 (a: strongly positive, b: weakly positive, $\mathbf{c}$ : negative) and $\mathrm{ET}_{\mathrm{A}} \mathrm{R}$ (d: strongly positive, e: weakly positive, f: negative) in OSCC. ET-1 immunoreactivity is observed in the cytoplasm and cell membrane of the tumor cells, and $\mathrm{ET}_{\mathrm{A}} \mathrm{R}$ immunoreactivity is observed in the cell membrane of the tumor cells (original magnification $\times 100$ ) 


\section{Statistical Analysis}

For the statistical analysis, JMP13.0 software (SAS Institute Inc., Cary, NC, USA) was used. Differences between pairs of groups were analyzed using the $\chi^{2}$ test, and $p<0.05$ was regarded as significant. The 5-year survival rates in the two groups were analyzed using the Kaplan-Meier method, and a multivariate analysis was performed using the Cox proportional hazard regression model.

\section{Results}

High levels of ET-1 expression were observed in the cytoplasm and cell membrane of the tumor cells, and high levels of $\mathrm{ET}_{\mathrm{A}} \mathrm{R}$ expression were observed in the cell membrane of the tumor cells (Fig. 1). Patients positive for both ET-1 and $\mathrm{ET}_{\mathrm{A}} \mathrm{R}$ showed their expressions in not only tumor cells but also stroma cells including fibroblasts, and all cases that showed expression in stroma cells also showed expression in tumor cells.

Table 1 Clinicopathological parameters in relation to ET-1 and $\mathrm{ET}_{\mathrm{A}} \mathrm{R}$ expression $(n=74)$

\begin{tabular}{|c|c|c|c|c|c|c|c|c|c|}
\hline \multirow[t]{2}{*}{ Variables } & \multirow[t]{2}{*}{$n$} & \multicolumn{3}{|c|}{ ET-1 no. $(\%)$} & \multirow[t]{2}{*}{$P$ value } & \multicolumn{3}{|c|}{$\mathrm{ET}_{\mathrm{A}} \mathrm{R}$ no. $(\%)$} & \multirow[t]{2}{*}{$P$ value } \\
\hline & & Strongly & Weakly & Negative & & Strongly & Weakly & Negative & \\
\hline Age, years & & & & & 0.28 & & & & 0.69 \\
\hline$<65$ & 35 & 17 (48.6) & $9(25.7)$ & $9(25.7)$ & & $16(45.7)$ & $9(25.7)$ & $10(28.6)$ & \\
\hline$\geq 65$ & 39 & $26(66.7)$ & 7 (17.9) & $6(15.4)$ & & $21(53.9)$ & $10(25.6)$ & $8(20.5)$ & \\
\hline Gender & & & & & 0.27 & & & & 0.26 \\
\hline Male & 36 & $21(58.3)$ & $10(27.8)$ & $5(13.9)$ & & $21(58.3)$ & $9(25.0)$ & $6(16.7)$ & \\
\hline Female & 38 & $22(57.9)$ & $6(15.8)$ & $10(26.3)$ & & $16(42.1)$ & $10(26.3)$ & $12(31.6)$ & \\
\hline Primary sites & & & & & 0.39 & & & & 0.94 \\
\hline Tongue & 39 & 19 (48.7) & $13(33.3)$ & $7(18.0)$ & & $21(53.9)$ & $10(25.6)$ & $8(20.5)$ & \\
\hline Buccal mucosa & 12 & $9(75.0)$ & $0(0.0)$ & $3(25.0)$ & & $6(50.0)$ & $3(25.0)$ & $3(25.0)$ & \\
\hline Upper gingiva & 12 & $8(66.7)$ & $1(8.3)$ & $3(25.0)$ & & $4(33.4)$ & $4(33.3)$ & $4(33.3)$ & \\
\hline Lower gingiva & 10 & $6(60.0)$ & $2(20.0)$ & $2(20.0)$ & & $5(50.0)$ & $2(20.0)$ & $3(30.0)$ & \\
\hline Others & 1 & $1(100.0)$ & $0(0.0)$ & $0(0.0)$ & & $1(100.0)$ & $0(0.0)$ & $0(0.0)$ & \\
\hline T category & & & & & 0.15 & & & & 0.16 \\
\hline $\mathrm{T} 1$ & 18 & $10(55.6)$ & $2(11.1)$ & $6(33.3)$ & & $6(33.3)$ & $3(16.7)$ & $9(50.0)$ & \\
\hline $\mathrm{T} 2$ & 36 & $19(52.8)$ & $12(33.3)$ & $5(13.9)$ & & $20(55.5)$ & $10(27.8)$ & $6(16.7)$ & \\
\hline $\mathrm{T} 3$ & 9 & $5(55.6)$ & $1(11.1)$ & $3(33.3)$ & & $4(44.5)$ & $3(33.3)$ & $2(22.2)$ & \\
\hline $\mathrm{T} 4$ & 11 & $9(81.8)$ & $1(9.1)$ & $1(9.1)$ & & $7(63.6)$ & $3(27.3)$ & $1(9.1)$ & \\
\hline $\mathrm{N}$ category & & & & & 0.58 & & & & 0.13 \\
\hline $\mathrm{N}(-)$ & 58 & $32(55.2)$ & $13(22.4)$ & $13(22.4)$ & & $28(48.3)$ & $13(22.4)$ & $17(29.3)$ & \\
\hline $\mathrm{N}(+)$ & 16 & $11(68.8)$ & $3(18.7)$ & $2(12.5)$ & & $9(56.3)$ & $6(37.5)$ & $1(6.2)$ & \\
\hline Stage & & & & & 0.07 & & & & 0.03 \\
\hline $\mathrm{S} 1$ & 16 & $9(56.3)$ & $1(6.2)$ & $6(37.5)$ & & $6(37.5)$ & $1(6.2)$ & $9(56.3)$ & \\
\hline $\mathrm{S} 2$ & 31 & $15(48.4)$ & $11(35.5)$ & $5(16.1)$ & & $16(51.6)$ & $9(29.0)$ & $6(19.4)$ & \\
\hline $\mathrm{S} 3$ & 11 & $6(54.5)$ & $2(18.2)$ & $3(27.3)$ & & $5(45.4)$ & $4(36.4)$ & $2(18.2)$ & \\
\hline $\mathrm{S} 4$ & 16 & $13(81.3)$ & $2(12.5)$ & $1(6.2)$ & & $10(62.5)$ & $5(31.3)$ & $1(6.2)$ & \\
\hline Cell differentiation & & & & & 0.08 & & & & 0.08 \\
\hline Well & 31 & $14(45.2)$ & $9(29.0)$ & $8(25.8)$ & & $15(48.4)$ & $6(19.4)$ & $10(32.2)$ & \\
\hline Moderate & 26 & $15(57.7)$ & $4(15.4)$ & 7 (26.9) & & $10(38.4)$ & $8(30.8)$ & $8(30.8)$ & \\
\hline Poor & 17 & $14(82.4)$ & $3(17.6)$ & $0(0.0)$ & & $12(70.6)$ & $5(29.4)$ & $0(0.0)$ & \\
\hline Mode of invasion & & & & & 0.04 & & & & $<0.01$ \\
\hline 1 & 5 & $1(20.0)$ & $2(40.0)$ & $2(40.0)$ & & $2(40.0)$ & $0(0.0)$ & $3(60.0)$ & \\
\hline 2 & 11 & $3(27.3)$ & $2(18.1)$ & $6(54.6)$ & & $2(18.2)$ & $2(18.2)$ & 7 (63.6) & \\
\hline 3 & 27 & $17(63.0)$ & $5(18.5)$ & $5(18.5)$ & & $12(44.5)$ & $9(33.3)$ & $6(22.2)$ & \\
\hline $4 \mathrm{C}$ & 21 & $15(71.4)$ & $4(19.1)$ & $2(9.5)$ & & $14(66.7)$ & $5(23.8)$ & $2(9.5)$ & \\
\hline $4 \mathrm{D}$ & 10 & $7(70.0)$ & $3(30.0)$ & $0(0.0)$ & & $7(70.0)$ & $3(30.0)$ & $0(0.0)$ & \\
\hline
\end{tabular}


Table 1 summarizes the relationship between clinicopathological factors and the expressions of ET- 1 and $\mathrm{ET}_{\mathrm{A}} \mathrm{R}$. Among the 74 OSCC patients, there were 43 patients who were strongly positive for ET-1 (58.1\%), 16 patients who were weakly positive for ET-1 (21.6\%). Thirty-seven of the patients were strongly positive for $\mathrm{ET}_{\mathrm{A}} \mathrm{R}(47.3 \%)$, and 19 patients were weakly positive for $\mathrm{ET}_{\mathrm{A}} \mathrm{R}(25.7 \%)$.

Regarding the clinical factors, no significant difference was observed in age, gender, the primary site, $\mathrm{T}$ classification, or $\mathrm{N}$ classification between the groups based on the expressions of ET-1 and $\mathrm{ET}_{\mathrm{A}} \mathrm{R}$, and there was a significant difference only between Stage and the $\operatorname{ET}_{\mathrm{A}} \mathrm{R}$ expression $(p=0.03)$. Concerning the degree of histopathological differentiation, a high proportion of cases expressing both $\mathrm{ET} 1$ and $\mathrm{ET}_{\mathrm{A}} \mathrm{R}$ was observed in the poorly differentiated squamous cell carcinomas, but no significant difference was found between the differentiation degree and the ET-1 and $\mathrm{ET}_{\mathrm{A}} \mathrm{R}$ expressions. Regarding the mode of invasion pattern, as the invasion progressed, the proportion of cases in which ET-1 and $\mathrm{ET}_{\mathrm{A}} \mathrm{R}$ were strongly or weakly expressed increased, and instead the percentage of negative cases decreased. A significant difference was observed
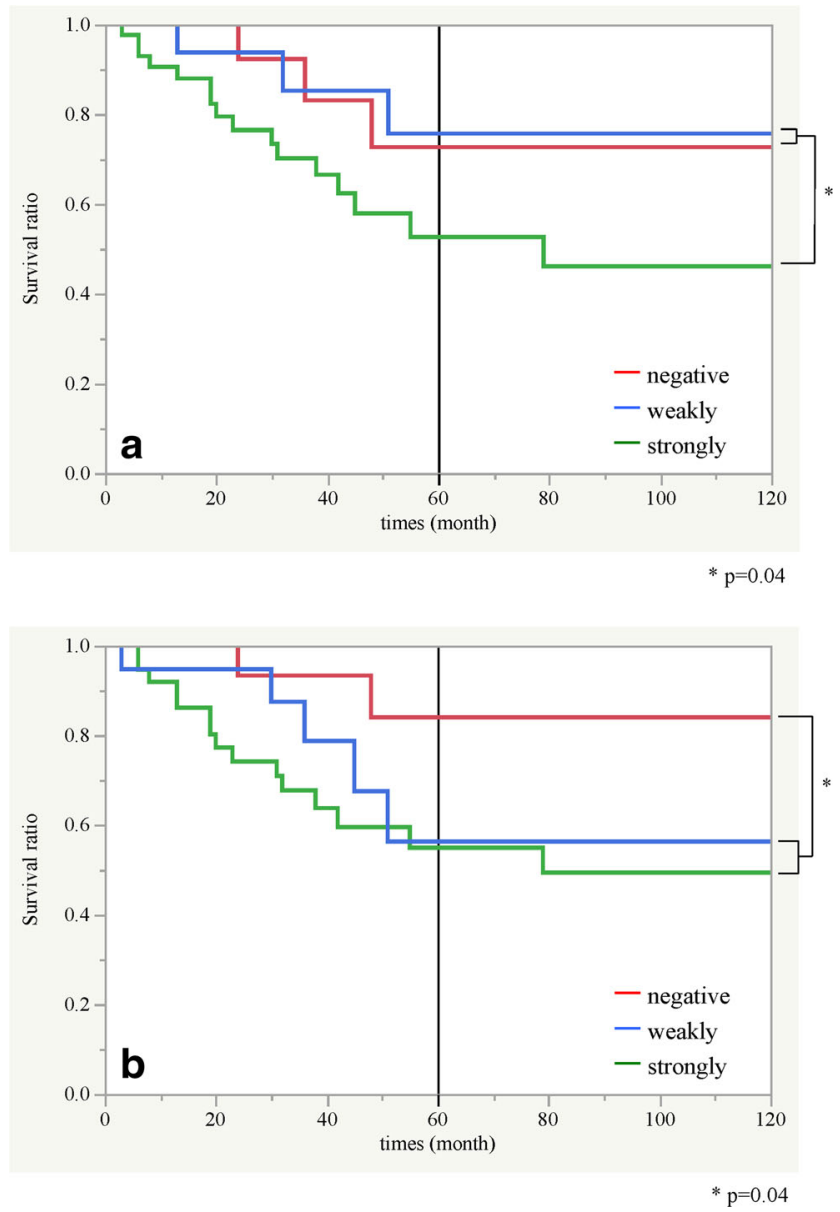

Fig. 2 Kaplan-Meier survival estimates for overall survival based on ET-1 (a) and $\mathrm{ET}_{\mathrm{A}} \mathrm{R}(\mathbf{b})$ expression between the mode of invasion and the expression of ET-1 ( $p=$ $0.04)$ and the expression of $\mathrm{ET}_{\mathrm{A}} \mathrm{R}(p<0.01)$.

We evaluated the relationship between the 5 -year cumulative survival rate and ET-1 or $\mathrm{ET}_{\mathrm{A}} \mathrm{R}$ expression. The 5-year cumulative survival rate of the patients who were strongly positive for ET-1 was $52.7 \%$, whereas the 5-year cumulative survival rates of negative and weakly positive patients were $72.7 \%$ and $75.8 \%$, respectively. The survival rate was significantly lower in the ET-1-positive patients than in the negative and weakly

Table 2 Clinicopathological parameters in relation to ET-axis expression $(n=74)$

\begin{tabular}{|c|c|c|c|c|}
\hline \multirow[t]{2}{*}{ Variables } & \multirow[t]{2}{*}{$n$} & \multicolumn{2}{|c|}{ ET-axis no. $(\%)$} & \multirow[t]{2}{*}{$P$ value } \\
\hline & & Positive & Negative & \\
\hline Age, years & & & & 0.17 \\
\hline$<65$ & 35 & $16(45.7)$ & $19(54.3)$ & \\
\hline$>65$ & 39 & $24(61.5)$ & $15(38.5)$ & \\
\hline Gender & & & & 0.83 \\
\hline Male & 36 & $19(52.8)$ & $17(47.2)$ & \\
\hline Female & 38 & $21(55.3)$ & $17(44.7)$ & \\
\hline Primary sites & & & & 0.52 \\
\hline Tongue & 39 & $19(48.7)$ & $20(51.3)$ & \\
\hline Buccal mucosa & 12 & $8(66.7)$ & $4(33.3)$ & \\
\hline Upper gingiva & 12 & $8(66.7)$ & $4(33.3)$ & \\
\hline Lower gingiva & 10 & $5(50.0)$ & $5(50.0)$ & \\
\hline Others & 1 & $0(0.0)$ & $1(100.0)$ & \\
\hline $\mathrm{T}$ category & & & & 0.16 \\
\hline $\mathrm{T} 1$ & 18 & $7(38.9)$ & $11(61.1)$ & \\
\hline $\mathrm{T} 2$ & 36 & $19(52.8)$ & $17(47.2)$ & \\
\hline $\mathrm{T} 3$ & 9 & $5(55.6)$ & $4(44.4)$ & \\
\hline $\mathrm{T} 4$ & 11 & $9(81.8)$ & $2(18.2)$ & \\
\hline $\mathrm{N}$ category & & & & 0.18 \\
\hline $\mathrm{N}(-)$ & 58 & $29(50.0)$ & $29(50.0)$ & \\
\hline $\mathrm{N}(+)$ & 16 & $11(68.8)$ & $5(31.2)$ & \\
\hline Stage & & & & 0.07 \\
\hline $\mathrm{S} 1$ & 16 & $6(37.5)$ & $10(62.5)$ & \\
\hline $\mathrm{S} 2$ & 31 & $15(48.4)$ & $16(51.6)$ & \\
\hline $\mathrm{S} 3$ & 11 & $6(54.5)$ & $5(45.5)$ & \\
\hline S4 & 16 & $13(81.3)$ & $3(18.7)$ & \\
\hline Cell differentiation & & & & $<0.01$ \\
\hline Well & 31 & $11(35.5)$ & $20(64.5)$ & \\
\hline Moderate & 26 & $15(57.7)$ & $11(42.3)$ & \\
\hline Poor & 17 & $14(82.4)$ & $3(17.6)$ & \\
\hline Mode of invasion & & & & $<0.01$ \\
\hline 1 & 5 & $0(0.0)$ & $5(100.0)$ & \\
\hline 2 & 11 & $2(18.2)$ & $9(81.8)$ & \\
\hline 3 & 27 & $16(59.3)$ & $11(40.7)$ & \\
\hline $4 \mathrm{C}$ & 21 & $15(71.4)$ & $6(28.6)$ & \\
\hline $4 \mathrm{D}$ & 10 & $7(70.0)$ & $3(30.0)$ & \\
\hline
\end{tabular}


Fig. 3 Kaplan-Meier survival estimates for overall survival based on ET-axis expression

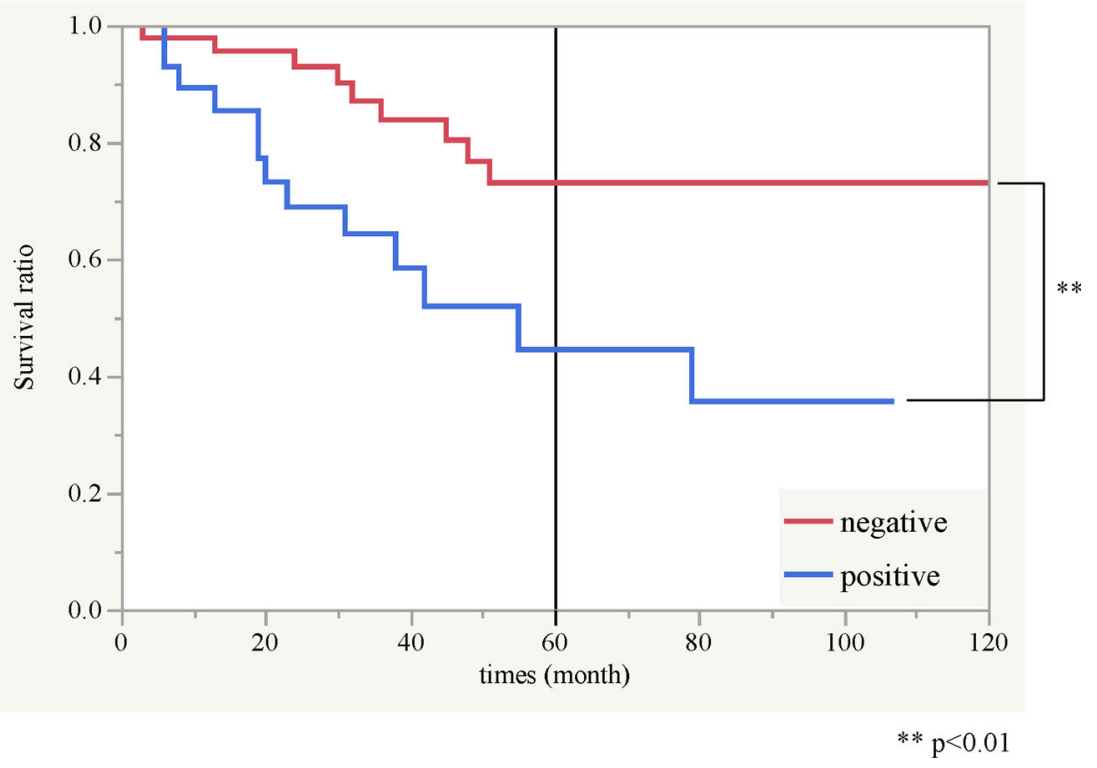

positive patients ( $p=0.04$, Fig. $2 \mathrm{a}$ ). In addition, the 5 -year cumulative survival rates of the patients who were strongly positive and weakly positive for $\mathrm{ET}_{\mathrm{A}} \mathrm{R}$ were $54.9 \%$ and $56.2 \%$, respectively, and the 5-year cumulative survival rate of the negative patients was $84.0 \%$. The survival rate was significantly lower in patients who were strongly or weakly positive for $\mathrm{ET}_{\mathrm{A}} \mathrm{R}$ compared to the negative patients ( $p=0.04$, Fig. $2 \mathrm{~b}$ ).

Based on the above results, we defined the cases in which ET-1 was strongly expressed and $\mathrm{ET}_{\mathrm{A}} \mathrm{R}$ was weakly and strongly expressed as ET-axis positive cases, and we defined the cases showing other expression patterns as negative cases. We examined the relationship between ET-axis expression and clinicopathological factors (Table 2). There was no significant difference in clinical factors, but there was a significant difference in histopathological factors. As the degree of differentiation decreased, and as the mode of invasion became higher, the proportion of ET-axis positive cases increased ( $p<0.01$, both factors). We next examined the relationship between ET-axis expression and the survival rate. The 5-year cumulative survival rate of the ET-axis-positive cases was $44.5 \%$, whereas that of the negative case was $73.1 \%$. There was a significant difference between the positive cases and negative cases $(p<0.01$, Fig. 3$)$.

The results of a univariate analysis showed significant associations between the survival rate and the degree of cell differentiation, the mode of invasion, ET-1 expression, $\mathrm{ET}_{\mathrm{A}} \mathrm{R}$ expression, and ET axis expression. However, a multivariate analysis showed no association between the survival rate and each of these factors, and each factor was not an independent prognostic factor (Table 3).

Table 3 Univariate and multivariate analyses for clinicopathological parameters, ET-1, $\mathrm{ET}_{\mathrm{A}} \mathrm{R}$, and ET-axis expression in relation to overall survival for 74 patients with OSCC

\begin{tabular}{|c|c|c|c|c|c|c|c|}
\hline \multirow[t]{2}{*}{ Variables } & \multirow[t]{2}{*}{ Clinical groups } & \multirow{2}{*}{$\begin{array}{l}\text { Survivors } \\
(n=52)\end{array}$} & \multirow{2}{*}{$\begin{array}{l}\text { Non-survivors } \\
(n=22)\end{array}$} & \multicolumn{2}{|c|}{ Log rank } & \multirow{2}{*}{$\begin{array}{l}\text { Cox regression } \\
P \text { value }\end{array}$} & \multirow[t]{2}{*}{ Risk ratio $(95 \% \mathrm{CI})$} \\
\hline & & & & $x^{2}$ & $P$ value & & \\
\hline $\mathrm{T}$ category & $\mathrm{T} 1-2 / \mathrm{T} 3-4$ & $39 / 13$ & $15 / 7$ & 0.926 & 0.3359 & & \\
\hline $\mathrm{N}$ category & $\mathrm{N}-/ \mathrm{N}+$ & $42 / 10$ & $16 / 6$ & 0.731 & 0.3927 & & \\
\hline Stage & $\mathrm{S} 1-2$ / S3-4 & $35 / 17$ & $12 / 10$ & 2.481 & 0.1152 & & \\
\hline Cell differentiation & Well / mod-poor & $26 / 26$ & $5 / 17$ & 5.953 & 0.0147 & 0.173 & $2.113(0.721-6.192)$ \\
\hline Mode of invasion & $1-3 / 4 C, 4 \mathrm{D}$ & $35 / 17$ & $8 / 14$ & 6.308 & 0.0120 & 0.215 & $1.812(0.708-4.642)$ \\
\hline ET-1 & $\mathrm{N}, \mathrm{W} / \mathrm{S}$ & $25 / 27$ & $6 / 16$ & 4.417 & 0.0356 & & \\
\hline $\mathrm{ET}_{\mathrm{A}} \mathrm{R}$ & $\mathrm{N} / \mathrm{W}, \mathrm{S}$ & $16 / 36$ & $2 / 20$ & 4.124 & 0.0423 & & \\
\hline ET-axis & $-/+$ & $28 / 24$ & $6 / 16$ & 6.635 & 0.0100 & 0.102 & $2.280(0.849-6.126)$ \\
\hline
\end{tabular}

$N$ Negative, $W$ weakly positive, $S$ strongly positive 


\section{Discussion}

In highly invasive squamous cell carcinoma, not only local progression but also a high late metastasis rate is associated with a poor prognosis. To understand the cell characteristics of OSCC and to search for prognostic factors, studies have been performed to evaluate the expressions of many genes and proteins, but prognostic factors have not yet been identified. It is thus necessary to discover novel biomarkers for OSCC.

In 1988, Yanagisawa et al. isolated a physiologically active substance (ET) with potent vasoconstriction activity from the supernatant of cultured porcine aortic endothelial cells, purified it, and determined the amino acid sequence [20]. The ETaxis consists of three types of 21 amino acid peptides, two types of rhodopsin-like G protein coupled receptor (GPCR), and endothelin-covering enzymes (ECEs). As a G proteincoupled receptor, $\mathrm{ET}_{\mathrm{A}} \mathrm{R}$ is expressed on the tumor and stroma cell membranes. After binding to ET-1, signals are transmitted from the inside of the cell to the nucleus by various routes. ET1 is thus considered to promote tumor cell proliferation and invasion due to autocrine and paracrine signaling [13].

This ET-axis activation is closely involved in the progression of various solid carcinomas, such as prostatic and ovarian carcinomas, and its mechanism has been clarified [11-16]. ET-1 has been reported to be associated with the growth and invasion of pulmonary cancer [21]. In hepatocellular carcinoma, $\mathrm{ET}_{\mathrm{A}} \mathrm{R}$ activation by ET-1 regulates cancer cell invasion and migration [22]. There have been few studies on the ETaxis (consisting of ET- 1 and $\mathrm{ET}_{\mathrm{A}} \mathrm{R}$ ) in OSCC, and the importance of its expression has not been evaluated. We therefore immunohistochemically determined the ET- 1 and $\mathrm{ET}_{\mathrm{A}} \mathrm{R}$ expressions in OSCC samples, and we investigated the association between their expressions and clinicopathological factors as well as prognosis.

Our evaluation of the possible association between ET-1/ $\mathrm{ET}_{\mathrm{A}} \mathrm{R}$ expression and clinicopathological factors revealed that ET-1 was significantly more frequently positive in patients with highly invasive carcinoma, which is similar to the results of previous studies $[11,15,16]$. Concerning $\mathrm{ET}_{\mathrm{A}} \mathrm{R}$ expression, there was a significant association between $\mathrm{ET}_{\mathrm{A}} \mathrm{R}$ expression and the mode of invasion, which is one of the OSCC's pathological indicators, and this result is similar to the results of previous findings [12]. our univariate analysis revealed a significant association between ET- 1 and $\mathrm{ET}_{\mathrm{A}} \mathrm{R}$ expressions and the survival rate. Wülfing et al. reported that ET-1 and its receptor expressions are useful prognostic factors in breast cancer [23], and our findings is similar. Moreover, our finding may be related to the malignancy characteristics of cancer cells as described above.

The present of evaluation of the possible association between ET-axis expression and clinicopathological factors showed a significant association between ET-axis expression and the degree of histological differentiation as well as the mode of invasion. Regarding the 5-year cumulative survival rate, the prognosis of the ET-axis-positive cases was significantly poor. Correlations between ET-1 and its receptor expressions and the malignancy grade were reported in breast cancer [23], and present study's results also suggests that the ET-axis is involved in the malignancy grade of OSCC.

In our multivariate logistic regression analysis, the expression of ET-1, $\mathrm{ET}_{\mathrm{A}} \mathrm{R}$, and ET axis were not independent prognostic factors, but our results suggest that in OSCC with high histopathological malignancy, a high mount of ET-1 is expressed and its binding to $\mathrm{ET}_{\mathrm{A}} \mathrm{R}$ activates the ET-axis signal and affects the progression of OSCC. Based on the abovedescribed results, we are convinced that an examination of the ET-axis expression in particular is important in estimating the prognoses of OSCC patients.

We evaluated the ET- 1 and $\mathrm{ET}_{\mathrm{A}} \mathrm{R}$ expressions in oral human squamous cell carcinoma tissue, and we observed that the evaluation of ET-axis expression as a co-expression of ET-1 and $\mathrm{ET}_{\mathrm{A}} \mathrm{R}$ may be important for estimating the progression and prognosis of OSCC. A review article suggested the clinical value of ET-axis as a therapeutic target in head and neck squamous cell carcinoma (HNSCC) [24] and there is a possibility that some ET-axis-positive patients respond to the ET receptor antagonists used for the treatment of prostatic cancer $[24,25]$. After further studies, the development of a novel treatment method using the ET-axis as the target is expected.

Open Access This article is distributed under the terms of the Creative Commons Attribution 4.0 International License (http:// creativecommons.org/licenses/by/4.0/), which permits unrestricted use, distribution, and reproduction in any medium, provided you give appropriate credit to the original author(s) and the source, provide a link to the Creative Commons license, and indicate if changes were made.

\section{References}

1. Nagao M, Tsugane S (2016) Cancer in Japan: prevalence, prevention and the role of heterocyclic amines in human carcinogenesis. Genes Environ 38:16

2. Karnoub AE, Dash AB, Vo AP, Sullivan A, Brooks MW, Bell GW, Richardson AL, Polyak K, Tubo R, Weinberg RA (2007) Mesenchymal stem cells within tumour stroma promote breast cancer metastasis. Nature 449:557-563

3. Orimo A, Gupta PB, Sgroi DC, Arenzana-Seisdedos F, Delaunay T, Naeem R, Carey VJ, Richardson AL, Weinberg RA (2005) Stromal fibroblasts present in invasive human breast carcinomas promote tumor growth and angiogenesis through SDF-1/CXCL12 serection. Cell 121:335-348

4. Orimo A, Weinberg RA (2006) Stromal fibroblasts in Cancer: a novel tumor-promoting cell type. Cell Cycle 5:1597-1601

5. De Wever O, Mareel M (2003) Role of tissue stroma in cancer cell invasion. J Pathol 200:429-447

6. Salani D, Taraboletti G, Rosano L, Di Castro L, Borsotti P, Giavazzi R, Bagnato A (2000) Endothelin-1 induces an Angiogenic 
phenotype in cultured endothelial cells and stimulates neovascularization in vivo. Am J Pathol 157:1703-1711

7. Grant K, Loizidou M, Taylor I (2003) Endothelin-1: a multifunctional molecule in cancer. Br J Cancer 88:163-166

8. Wulfing P, Kersting C, Tio J, Fischer RJ, Wulfing C, Poremba C, Diallo R, Bocker W, Kiesel L (2004) Endothelin-1, endothelin-A-, and endothelin-B- receptor expression is correlated with vascular endothelial growth factor expression and angiogenesis in breast Cancer. Clin Cancer Res 10:2393-2400

9. Kiowski W, Kim J, Oechslin E, Sutsch G, Hunziker P, Muller P, Bertel O, Schmitt R, Jones R (1995) Evidence for endothelin-1mediated vasoconstriction in severe chronic heart failure. Lancet 346:732-736

10. Ohkita M, Takaoka M, Matsumura Y (2007) Endothelin-1 production and its involvement in cardiovascular diseases. Yakugaku Zasshi 127:1319-1329

11. Nelson JB, Chan-Tack K, Hedican SP, Magnuson SR, Opgenorth TJ, Steven Bova G, Simons JW (1996) Endothelin-1 production and decreased endothelin B receptor expression in advanced prostate Cancer. Cancer Res 56:663-668

12. Gohji K, Kitazawa S, Tamada H, Katsuoka Y, Nakajima M (2001) Expression of endothelin receptor A associated with prostate cancer progression. J Urol 165:1033-1036

13. Rosanò L, Spinella F, Bagnato A (2013) Endothelin 1 in cancer: biological implications and therapeutic opportunities. Nat Rev Cancer 13:637-651

14. Nelson J, Bagnato A, Battistini B, Nisen P (2003) The endothelin axis: emerging role in cancer. Nat Rev Cancer 3:110-116

15. Nelson JB, Hedican SP, George DJ, Reddi AH, Piantadosi S, Eisenberger MA, Simons JW (1995) Identification of endothelin1 in the pathophysiology of metastatic adenocarcinoma of the prostate. Nat Med 1:944-949

16. Bagnato A, Tecce R, Moretti C, Di Castro V, Spergel D, Catt KJ (1995) Autocrine actions of endothelin-1 as a growth factor in human ovarian carcinoma cells. Clin Cancer Res 1:1059-1066
17. (2009) International Union against cancer. In: Sobin LH, Gospodrowicz MK, Wittekind CH (eds) TNM classification of malignant tumours, 7th edn. Wiley-Liss, New York

18. Yamamoto E, Kohama G, Sunagawa H, Iwai M, Hiratsuka H (1983) Mode of invasion, bleomycin sensitivity, and clinical course in squamous cell carcinoma of the oral cavity. Cancer $51: 2175-2180$

19. Kato K, Kawashiri S, Tanaka A, Noguchi N, Nakaya H, Hase T, Yamamoto E (2008) Predictive value of measuring p53 labeling index at the invasive front of oral squamous cell carcinomas. Pathol Oncol Res 14:57-61

20. Inoue A, Yanagisawa M, Kimura S, Kasuya Y, Miyauchi T, Goto K, Masaki T (1989) The human endothelin family; three structurally and pharmacologically distinct isopeptides predicted by three separate genes. PNAS 86:2863-2867

21. Zhang ZY, Chen LL, Xu W, Sigdel K, Jiang XT (2017) Effects of silencing endothelin-1 on invasion and vascular formation in lung cancer. Oncol Lett 13:4390-4396

22. Cong N, Li Z, Shao W, Li J, Yu S (2016) Activation of ETA receptor by Endothelin-1 induces hepatocellular carcinoma cell migration and invasion via ERK1/2 and AKT signaling pathways. J Membr Biol 249:119-128

23. Wülfing P, Diallo R, Kersting C, Wülfing C, Poremba C, Greb RR, Böcker W, Kiesel L (2004) Endothelin-1, endothelin-A- and endothelin-B-receptor expression in preinvasive and invasive breast disease. Oncol Rep 11:791-796

24. McKenzie GA, Hinsley EE, Hunter K, Lambert DW (2014) The endothelin axis in head and neck cancer: a promising therapeutic opportunity? J Oral Pathol Med 43:395-404

25. Hoffmann RR, Yurgel LS, Campos MM (2010) Endothelins and their receptors as biological markers for oral cancer. Oral Oncol 46: 644-647 